\title{
Battling Parkinson's Law
}

I t's hard to imagine that Sonny Curtis knew about Parkinson's Law when he wrote the song "I Fought the Law." The song has achieved a place in rock history at the hands of The Clash, but the law has received comparatively less play in our collective consciousness. I would have never become interested in Dr. Parkinson's musings had I not stumbled across them on a radio program celebrating the life of Lister Sinclair, the previous host of the CBC Radio program, Ideas. It was at that point that I became aware that this law represents an important lesson on surviving as a resident and practising physician.

Parkinson's Law states: "Work expands so as to fill the time available for its completion." It was first conceived of by C. Northcote Parkinson in a 1955 article in The Economist. ${ }^{1}$ The idea was born from the observation that as the British overseas empire declined in influence, the number of employees at colonial offices increased. The basic theory postulates that the volume of work and the number of employees do not necessarily correlate with one another. Further interpretations of the law have led to applications in the computer industry related to the storage of data on hard drives. Looking through the daily barrage of computer ads, one notices the constant increase in the size of data storage devices. Yet, any computer owner will attest to the fact that regardless of the increase in capacity, storage space always seems to be lacking.

My life in an orthopedic surgery training program is another case in point of this law. Over 2 years of residency, I have noted that free time has slowly been wrestled from me. As my efficiency increases, daily duties take far less time, but free time still eludes me and the number of tasks I must complete spirals out of control. Former interests have become afterthoughts as preparation for rounds and studying anatomy take an increasingly prominent position in my daily routine. Even though I am told that becoming a well-rounded individual is important to



improving my practice of medicine, it is becoming apparent that Parkinson's postulate will win out in the end.

My plight is not unique. Many of my peers are also succumbing to the edicts of Parkinson. The modern Western world demands that youth become increasingly specialized and singularly focused on a narrow field within any given occupation. In my field, many entrants graduated from high school with a fully formed road map to guide them along their career path. Personal sacrifices were expected and accepted with little more than a passing thought. I found myself pulled irresistibly into the depths of this world.

Now that I've realized the seeping, single-track slant that my life was taking, I've decided to take back a measure of control. The biggest fear a surgical trainee should have is becoming oblivious to their environment and losing track of the "now." In understanding Parkinson's Law I have begun to appreciate the significance of moments. Whereas I previously needed a large amount of free time to appreciate freedom and detachment from the confines of the hospital, I now need a comparatively short absence. As life's schedule fills up, one must tailor it to maintain these breaks. They may come in the form of a breeze coming across the Red River on my ride into work. Some moments may present themselves as a glimpse of 3 characters sitting together on a park bench in heated discussion.

I can pretty much guarantee that Joe Strummer was not pondering medical resident life when he wrote "Complete Control" either, but the title begs a question: How do we maintain complete control in the face of limited time? It is clear to me that as I progress through training and into practice my time will be filled irrespective of my efficiency and industry. I believe the footprint left by the pressure of our daily duties has a major impact on our well-being and self-image. Awareness of Parkinson's Law is a tool in our belt, but also a thorn in our side. Will there ever be enough time again? Perhaps what we need to do, instead of dwelling on the demands on our time, is to focus on the ways we can expand the spaces in between.

\section{Jesse Alan Shantz MD \\ Orthopedic surgeon \\ Winnipeg, Man.}

\section{REFERENCE}

1. Parkinson CN. Parkinson's law: or, The pursuit of progress. London: J. Murray; 1958.

Have you got an opinion about this article? Post your views at www.cmaj.ca. Potential Salon contributors are welcome to send a query to salon@ cma.ca. 